4

5 Balsam Qubais Saeed ${ }^{1,2} *$, Rula Al-Shahrabi ${ }^{2}$, Obasanjo Afolabi Bolarinwa ${ }^{3}$

${ }^{1}$ Department of Clinical Sciences, College of Medicine, University of Sharjah, P.O. Box 27272,

Sharjah, UAE. E-mail; bsaeed@sharjah.ac.ae

${ }^{2}$ Sharjah Institute for Medical Research, University of Sharjah, P.O. Box 27272, Sharjah, UAE.

E-mail; ph.rulaali@gmail.com

${ }^{3}$ Department of Public Health Medicine, School of Nursing and Public Health, University of KwaZulu-Natal, Durban, South Africa. E-mail; bolarinwaobasanjo@gmail.com

ORCID - https://orcid.org/0000-0002-9208-6408

13

4

15

(6)

7

*Correspondence: Balsam Qubais Saeed, email: bsaeed@ sharjah.ac.ae, Tel: 00971605057235

(1)

0

1

2

3

4

\title{
Socio-demographic correlate of knowledge and practice toward novel coronavirus among people living in Mosul-Iraq: A cross-sectional study
}

5


medRxiv preprint doi: https://doi.org/10.1101/2020.09.11.20192542; this version posted September 11, 2020. The copyright holder for this preprint (which was not certified by peer review) is the author/funder, who has granted medRxiv a license to display the preprint in perpetuity.

It is made available under a CC-BY 4.0 International license .

ABSTRACT

Background: Since the World Health Organization (WHO) announced that the 2019 novel coronavirus (2019-nCoV) is a worldwide pandemic, as the Iraqi authorities have started responding and taking action to control the spread of the pandemic. The knowledge and practices of the public play an important role in curbing the spreading of the virus by following the health guidelines. This study aimed to assess the socio-demographic correlate of knowledge and practices of Iraqi living in Mosul-Iraq towards novel coronavirus during its rapid rise.

Methods: A cross-sectional online survey of 909 participants was conducted among Mosul-Iraq

34 between $20^{\text {th }}$ June to $1^{\text {st }}$ July 2020. The survey included three parts: 1) socio-demographic characteristics, 2) participants' knowledge, 3) participants' practices. T-test, ANOVA, chi-square, and binary logistic regression were used. A p-value less than 0.05 ( $\mathrm{p}<0.05)$ was considered

37 statistically significant.

Results: The results showed knowledge and practice mean score of (12.91 \pm 1.67$)$ and $(21.56 \pm$ 2.92) with cumulative knowledge and practice of $86 \%$ and $76 \%$ respectively towards 2019 nCoV. Socio-demographic characteristics such as age, marital status, gender, level of education and employment were statistically related with a higher mean score of knowledge and practice

42 towards the virus as $P<0.05$.

43 Conclusions: We concluded that the majority of the respondents demonstrate a high level of 44 knowledge and practices towards 2019-nCoV except respondents with socio-demographic 45 characteristics such as those who were younger, male respondents, those with lower education 46 and those unemployed as such campaigns that will increase the knowledge and encourage 47 adequate preventive practice towards 2019-nCoV should be targeted towards this group. 
medRxiv preprint doi: https://doi.org/10.1101/2020.09.11.20192542; this version posted September 11, 2020. The copyright holder for this preprint (which was not certified by peer review) is the author/funder, who has granted medRxiv a license to display the preprint in perpetuity.

It is made available under a CC-BY 4.0 International license .

KEYWORDS: Knowledge, Practice, Novel coronavirus, Mosul, Iraq

\section{INTRODUCTION}

51 On $31^{\text {st }}$ December 2019, the novel coronavirus detected in Wuhan, China, on 11-March 2020,

52 has been considered as a global pandemic by the (WHO), at the end of April, the virus has spread

53 worldwide with fear-evoking death reports $(1,2)$.

54 The 2019 novel coronavirus (2019-nCoV) is highly contagious; it causes a respiratory illness that

55 ranges from the common cold-like symptoms to more severe diseases (2). Most of the infected

56 patients complaining from fever, shortness in breath, cough, loss of smell, and/or taste sensation

57 and might be infected asymptomatically. In severe cases, patients might suffer from pneumonia,

58 multiple organ dysfunction, and death. $(3,4)$.

The 2019-nCoV is a novel strain that is not specified in humans earlier, and it is a zoonotic

illness that is transmitted between animals and people and may infect humans and animals. (5).

In Iraq, the first case of novel coronavirus was confirmed on $24^{\text {th }}$-February-2020 in Al-Najaf

62 city by people who have visited Iran. Therefore, at the end of March 13-2020, the Ministry of

63 Health and Environment of Iraq declared that the total of confirmed cases of coronavirus is

64 101(6). The ministry of health $(\mathrm{MOH})$ in Iraq started to respond and take action to control the

65 infection, as well as the technical observation of (WHO), three governmental biological

66 laboratories in Baghdad, Basrah, and Erbil, were opened for COVID-19 outbreak testing. (7).

67 Initially, the measures that were taken by the Iraqi authorities nationwide have succeeded in 
medRxiv preprint doi: https://doi.org/10.1101/2020.09.11.20192542; this version posted September 11, 2020. The copyright holder for this preprint (which was not certified by peer review) is the author/funder, who has granted medRxiv a license to display the preprint in perpetuity. It is made available under a CC-BY 4.0 International license .

70

71

72

73

74

75

76

77

78

79

80

81

82

reported compared to the previous months, while the reported national cases rose from 10,000 to 120,000 across the country (8).

Due to the escalating number of cases in Mosul city, many challenges were observed while trying to stop the virus from spreading, the limited number of tests that can be carried out per day, lack of quarantine facilities, medical instrument, hygienic preparation insufficiency, low hospital capacities, and no approved medicine or vaccine to prevent the 2019 n-CoV. Therefore, the preventive measures taken by the people are important to protect themselves and others from the virus infection and control the spread of the disease (9). Thus, managing this crisis hangs primarily on people's knowledge and practices toward this virus and following all the precautions to prevent cross-infection and follow guidelines of the World Health Organization (WHO) and the Center for Disease Control and Prevention (CDC) (10, 11 ).

World Health Organization (WHO) declared precautional strategies to curb the spreading of infections. The none medical precautions are maintaining social distancing, avoid public gathering, avoid direct contact with infected people and use of personal protective equipment (PPE) like face masks. Also, personal hygiene recommendations such as hand-washing often with soap and water for at least 20 seconds, especially after touching surfaces, don't touch the nose, eyes, and mouth with unwashed hands, and self-isolate when 2019-nCoV symptoms started (10).

The knowledge and practices of the public toward 2019 novel coronavirus play an important role in determining the willingness of Iraqi citizens to change their behavior and identify the kind of intervention that is needed to correct the misconceptions regarding the virus, highlight the poor knowledge toward the virus and disease, development of new preventive measures, develop COVID-19 awareness campaign, and take precautionary. Therefore, the current study aimed to 
medRxiv preprint doi: https://doi.org/10.1101/2020.09.11.20192542; this version posted September 11, 2020. The copyright holder for this preprint (which was not certified by peer review) is the author/funder, who has granted medRxiv a license to display the preprint in perpetuity.

It is made available under a CC-BY 4.0 International license .

93 assess the socio-demographic correlate of knowledge and practices of Iraqi in Mosul towards

942019 novel coronavirus during its rapid rise.

95 The results of this study are expected to provide baseline information about the level of

96 knowledge and practices of Iraqi living in Mosul and highlight misperceptions related to

97 preventive measures. The outcomes of the study will further hence better planning for effective

98 awareness campaigns, required interventions and taking the appropriate action from local

99 authorities.

100

\section{MATERIAL AND METHODS}

101 Study design

102 A cross-sectional survey was adopted for the study using an online google form platform. The

103 invitation of the respondents (Mosul-Iraqi) to participate in the survey was made on social media

104 using the most popular media in Iraq, the social media messenger applications such as;

105 WhatsApp and Facebook messengers were used in distributing the online google based

106 questionnaire and participation was limited to Mosul-Iraqi 18 years and above.

\section{Study Settings}

108 Mosul is located in Nineveh Governorate - Iraq, has a population of 3.5 million. Residents of 109 Mosul city suffer from a fragile health system that barely meets their basic needs, as many health 110 facilities were destroyed in 2017 (8).

\section{Survey and data collection}

112 A total of 909 Mosul-Iraqi participated in our study between 20th June to 1st July 2020. The

113 specified Sample size was by determining the lowest acceptable size of a demographic subgroup

114 with a $\pm 5 \%$ margin of error and a confidence level of $95 \%(12,13)$. Giving to this, out of the 
medRxiv preprint doi: https://doi.org/10.1101/2020.09.11.20192542; this version posted September 11, 2020. The copyright holder for this preprint (which was not certified by peer review) is the author/funder, who has granted medRxiv a license to display the preprint in perpetuity.

It is made available under a CC-BY 4.0 International license .

115

116

117

118

119

120

121

122

123

124

125

126

127

128

129

130

131

132

133

134

135

136

137

total respondents of 1121 who filled the online google based questionnaire, only 909 were included. An incomplete survey of participants of 212 was excluded from the study, leaving us with a completion rate of $81 \%$.

The survey was an adapted version of questionnaires published previously $(14,15,16)$. The survey was reviewed, and pilot tested by 21 Iraqi people and 3 faculty experts at the University of Mosul using WhatsApp and telephone interviews to correct any question then sent it to the target population. The survey consisted of an interface page and three main themes, with a total of 37 questions. The interface page included the title, objective of the study, information on participants' privacy, and instructions to fill the survey. The three main themes included: 1) demographic information of participants such as gender, age, education level, marital status, employment status, coronavirus test, coronavirus result and Chronic diseases; 2) Knowledge related the 2019 novel coronavirus consisted of 15 questions divided to clinical presentations of virus (K1-K5), the spread of the virus (K6-K9) prevention (K10-K12) and the risk factors (K13K15); 3) practices of participants toward novel coronavirus outbreak, which included 13 questions. The google based questionnaire was designed in Arabic to encourage adequate participation of the respondents since Arabic is the common language in Mosul city.

\section{Ethical approval}

The Research Ethics Committee (RIC) at the University of Sharjah, UAE approved this study by the reference number is REC- 20-05-31-01, as of 14/06/2020.

\section{Data and statistical analysis}

Data analysis conducted using Statistical Package for Social Software (SPSS) version 22. Scale reliability was performed to ensure data consistency (Cronbach's alpha coefficient $=0.729$ ), indicating good consistency. The frequencies of demographic characteristics, knowledge, and 
medRxiv preprint doi: https://doi.org/10.1101/2020.09.11.20192542; this version posted September 11, 2020. The copyright holder for this preprint (which was not certified by peer review) is the author/funder, who has granted medRxiv a license to display the preprint in perpetuity.

It is made available under a CC-BY 4.0 International license .

138

139

140

141

142

143

144

145

146

147

148

149

150

151

152

153

154

155

156

157

158

159

160

practice answers along with descriptive statistics, were presented in mean $\pm \mathrm{SD}$, while qualitative data were presented in frequency (numberlpercent). Participants' knowledge and practice scores were compared with demographics factors using independent- samples t-test, one-way analysis of variance (ANOVA).

To measure the knowledge, participants were given "yes," "no," and "not sure" answer options to each survey question. A true answer to each question was marked with 1 score, while false answers and not sure were marked with 0 scores. Scores of total knowledge ranged from 0-15; a higher score signals a better level of knowledge. To practice measures, participants were given "always", "sometimes", and " never" answer options to each item; the always option was marked for 2 scores, while sometimes was for 1 score, and rarely was for 0 scores. The total practice scores ranged from 0-26. The lowest and highest score of participants' knowledge was 7 and 15, respectively, while the lowest and highest score of practice was 14 and 26, respectively.

Pearson's chi-square was used to determine the association between the explanatory and outcome variables. We examined the factors associated with good knowledge \& practice and poor knowledge \& practices by using binary logistic regression analyses. A p-value of less than $0.05(\mathrm{p}<0.05)$ was considered statistically significant.

To identify the factors that were significantly associated with good or poor knowledge and practices, a mean knowledge score of more than 12 indicated as good knowledge, while less than 12 assigned as poor. Similarly, a mean practice score above 21 indicated as good practice and a mean practice score below 21 as poor practice. Factors were selected with a backward stepwise method, and the reference category was selected based on the higher total mean. Unstandardized regression coefficients $(\beta)$ and odds ratios (ORs) and their $95 \%$ confidence intervals (CIs) were used to quantify the associations between cofactors with knowledge and practice. 
medRxiv preprint doi: https://doi.org/10.1101/2020.09.11.20192542; this version posted September 11, 2020. The copyright holder for this preprint (which was not certified by peer review) is the author/funder, who has granted medRxiv a license to display the preprint in perpetuity.

It is made available under a CC-BY 4.0 International license.

161

162

163

164

165

166

167

168

169

170

171

172

173

174

175

176

177

178

179

180

181

182

183

184

185

\section{RESULTS}

\section{Socio-demographic characteristics}

The results showed that the majority of $61.4 \%$ were females, and $38.6 \%$ were males. More than half of the participants, 54.5\%, aged 30-49 years. Around $60.5 \%$ of respondents were married, while $31.7 \%$ and $7.9 \%$ were single, and others (divorced and widows), respectively. About $62.4 \%$ were holding a bachelor's degree, while $25.7,11.9 \%$ were holding postgraduates and diploma or below, respectively. Moreover, almost $64.5 \%$ were employed, while a smaller number of participants, $21.8 \%, 13.9 \%$, were unemployed and students, respectively. Some of the participants, $7.9 \%$, have been tested for COVID-19, while 92.1\% didn't do the COVID-19 est. However, $1.5 \%$ of tested respondents were positive, and $98.5 \%$ of the participants have been negative tests. Figure 1 summarized the frequency of respondents according to demographic characteristics.

\section{Prevalence of chronic diseases reported by Iraqi participants}

In our study, $82.4 \%$ of the participants were healthy, while $17.6 \%$ had chronic diseases. The most common chronic diseases were diabetes $6 \%$, followed by asthma at $3.30 \%$. Moreover, $2.75 \%, 2.40 \%, 1.54 \%, 1.54 \%, 1.20 \%$ had chronic kidney disease, severe obesity, heart conditions, chronic liver disease, and chronic lung diseases, respectively, as shown in Figure 2.

\section{Knowledge towards novel coronavirus}

The mean knowledge score $( \pm \mathrm{SD})$ of 15 questions was $(12.91 \pm 1.67)$. The correct percentage rate was $86.08 \%$. Most of the participants, $92.1 \%$, answered correctly that novel coronavirus caused by a virus; the majority, $94.1 \%$, knew that the incubation period range of this virus is between 2 14 days. Almost all participants had a high knowledge of $96 \%$ about the symptoms of a novel coronavirus; about $72.3 \%$ of respondents knew that no vaccine toward this virus. 
medRxiv preprint doi: https://doi.org/10.1101/2020.09.11.20192542; this version posted September 11, 2020. The copyright holder for this preprint (which was not certified by peer review) is the author/funder, who has granted medRxiv a license to display the preprint in perpetuity.

It is made available under a CC-BY 4.0 International license .

186

187

188

189

190

191

192

193

194

195

196

197

198

199

200

201

202

203

204

205

206

207

208

Moreover, 63.4\% knew that no treatment was approved toward novel coronavirus until now. When we asked if this virus is spread via respiratory droplets of infected people, $93.1 \%$ answered correctly.

Similarly, A high proportion of $93.1 \%$ of the participants agreed that the virus could be transmitted via touching contaminated surfaces. Also, $82.2 \%$ indicated that this virus was transmitted through the eyes, nose, and mouth. Just over half, 59.4\%, reported that the infected person having no fever could infect healthy people and the majority of participants, $94.1 \%$ recorded that children and young adults have to take measures toward novel coronavirus.

About $76.2 \%$ of respondents reported the individuals should stay at home and go out only when necessary, while all of the participants $100 \%$ agreed that they should avoid going to crowded places, and the infected person with this virus should be immediately isolated in a proper place. Most of the respondents, $96 \%$, answered that the virus is more dangerous for those with chronic disease patients and the elderly, while $79.2 \%$ believed that smokers are more vulnerable to this virus. The knowledge of participants toward novel coronavirus is displayed in Table 1.

\section{Practice towards novel coronavirus}

The mean practice score $( \pm \mathrm{SD})$ of 13 questions was $(21.56 \pm 2.92)$. The correct percentage rate was $75.8 \%$. We found that $92.1 \%$ of the participants started washing their hands frequently during a novel coronavirus period. Similarly, $92.1 \%$ indicated they were used sanitizer if the soap is not available, while usual handwashing with soap for 20 seconds was recorded by $77.2 \%$ of respondents. Almost $83.2 \%$ of participants wearied a mask when they go outside the home. Three-quarters, $72.3 \%$ of respondents maintain space between them and others when going outside, and only $36.6 \%$ maintain the 2 -meter distance between them and others to prevent transmission of the virus. 
medRxiv preprint doi: https://doi.org/10.1101/2020.09.11.20192542; this version posted September 11, 2020. The copyright holder for this preprint (which was not certified by peer review) is the author/funder, who has granted medRxiv a license to display the preprint in perpetuity.

It is made available under a CC-BY 4.0 International license .

209

210

211

212

213

214

215

216

217

218

219

220

221

222

223

224

225

226

227

228

229

230

231

About $88 \%$ of the Iraqi respondents stopped going to crowded places recently. However, twothirds of the respondents, $69.3 \%$ and $65.3 \%$, reported that they stopped visiting and kissing their relatives or friends when meeting them, while $77.2 \%$ stopped the handshake during the greeting with others. Besides, $81.2 \%$ were aware of the essential of sanitizing their hands after using cash, and $75.2 \%$ of participants were aware of the importance of avoiding sharing their food with others. The participant's practices toward novel coronavirus prevention presented in Table 2 .

\section{Sources of information on COVID-19}

Participants indicated that the Ministry of Health and Environment in Iraq (MOH) and social media such as Twitter, Facebook, YouTube, WhatsApp, Instagram, and Snapchat were the main sources of information about novel coronavirus pandemic with $60.3 \%$ and $57.5 \%$ respectively, followed by World Health Organization (WHO) press release 41.6\%, while $28.7 \%$, 15.8\%, and $1.4 \%$ reported that they received their information from the news outlet, family and friends, and other sources, respectively as presented in Figure 3.

\section{Level of knowledge (K) and practice (P) as per socio-demographic characteristics of participants}

The knowledge level score (out of 15) showed a significant association across sociodemographic characteristics such as gender, age, education levels, marital status, and employment status ( $\mathrm{p} \square<0.005$ ). The practice level score (out of 26) also showed a significant association between gender and age-groups $(\mathrm{p} \square<0.005)$ while there was no significant association between marital status $((\mathrm{p}=0.061)$, educational $(\mathrm{p}=0.385)$ and employment $(\mathrm{p}=0.084)$ with the practice of the participants.

The results indicated that females had a higher mean score of knowledge $(13.19 \pm 1.70)$ and practice $(21.85 \pm 2.61)$ than males, aged group of participants above 50-years-old having the 
medRxiv preprint doi: https://doi.org/10.1101/2020.09.11.20192542; this version posted September 11 , 2020. The copyright holder for this preprint (which was not certified by peer review) is the author/funder, who has granted medRxiv a license to display the preprint in perpetuity.

It is made available under a CC-BY 4.0 International license .

232 highest score of knowledge $(14.11 \pm 0.87)$ and practice $(22.50 \pm 2.32)$ compared with other age 233 groups. Moreover, widows and divorced women's knowledge $(13.37 \pm 1.32)$ were higher than 234 singles and married participants; however, there were no significant differences in practice. The 235 mean score of knowledge $(13.26 \pm 1.51)$ and practice $(21.75 \pm 2.77)$ of participants with high 236 education degrees were better than participants with lower educational degrees. Employed 237 respondents showed a higher-level score of knowledge (13.12 \pm 1.61$)$ than non-employed and 238 students' participants. While there were no significant differences in employment status in 239 practice, neither education levels nor employment status had any significant differences in 240 practice, as depicted in table 3.

\section{Binary logistic regression analysis}

242 Table 4 shows the binary logistic regression analysis on variables significantly correlated with

243 knowledge and practice (good and poor) about 2019 novel coronavirus.

244 The Odds ratios (ORs) and their 95\% confidence intervals (CIs) in a bid to quantify the 245 relationship between socio-demographic characteristics and the knowledge score $(>12$ and $<12)$, 246 and between socio-demographic characteristics and the practices score $(>21$ and $<21)$. Overall,

247 the analysis presents a significant relationship between knowledge with age, marital status, and 248 employment status. The same table shows that the age of $\geq 50$ vs other ages reported better 249 knowledge, divorced \& widows vs. married and single participants were significantly related 250 with a higher mean score, employed people were significantly related with the better knowledge 251 vs unemployed and retired respondents ( $\beta$ :-1.790, OR: 0.167, CI: 0.103-.270). Moreover, gender, 252 age, education and employment status were significantly associated with good practices. Female 253 gender vs male ( $\beta$ : -0.458 OR: 0.633 , CI $0.464-0.863$ ), age group of $\geq 50$ had higher practice 254 score than the youngest group of $18-29$ and 30-49 ( $\beta$ : -0.790 , OR: 0.454, CI: $0.261-0.788),(\beta$ : - 
medRxiv preprint doi: https://doi.org/10.1101/2020.09.11.20192542; this version posted September 11, 2020. The copyright holder for this preprint (which was not certified by peer review) is the author/funder, who has granted medRxiv a license to display the preprint in perpetuity.

It is made available under a CC-BY 4.0 International license .

255

256

257

258

259

260

261

262

263

264

265

266

267

268

269

270

271

272

273

274

275 The high level of knowledge among the public may be due to most of the participants having a

276

277

0.890 OR: 0.411, CI: 0.266-0.635), respectively. However, participants with a college-level degree and below showed a better practice ( $\beta$ 1.450 OR: 4.263, 95\% CI: 2.206-8.236) than participants with a postgraduate degree, while, employment statues of employed reported a better score than unemployed participants to ( $\beta$ : -1.215 , OR: 0.297 , CI: $(0.158-0.558)$, as indicated in Table 4.

\section{DISCUSSION}

The knowledge and practices of the public play an important role in prevention by following the health guidelines to control the spread of 2019-nCoV. The knowledge and practices of the general population about novel coronavirus have changed during the pandemic as a defense line against the disease.

The provided baseline data regarding the level of individuals' knowledge on clinical presentations, transmission, prevention, and risk factors of novel coronavirus virus will help highlight malpractices related to preventive measures hence making it critical for local authorities to plan suitable strategies to prepare and manage the spread of the virus.

The current study resulted that the participants' knowledge was high (86\%) and had good measures of practice toward 2019 novel coronavirus (76\%). Similar to our findings, several studies done in many countries have reported high levels of knowledge about novel coronavirus, among the general population in Malaysia 80.5\%, Chinese residents 90\%, Saudi Arabia population $81.5 \%$, and among healthcare workers in Pakistan 93.2\%. $(14,4,15,16)$. college degree or higher, or due to the high level of media coverage, including all media outlets and the impact of the pandemic on social life mandating that people follow. 
medRxiv preprint doi: https://doi.org/10.1101/2020.09.11.20192542; this version posted September 11, 2020. The copyright holder for this preprint (which was not certified by peer review) is the author/funder, who has granted medRxiv a license to display the preprint in perpetuity.

It is made available under a CC-BY 4.0 International license.

278 The current results showed that most of the participants depend more on the ministry of health

279 and social media to get their information about the 2019 novel coronavirus, In contrast to other

280 studies among Jordanian, Egyptian and Pakistani populations that were using mostly social

281 media as the main source of information $(17,18,19)$.

282 The study found that the majority of respondents had a good level in prevention and control

283 measures toward novel coronavirus, indicating that the practices of some respondents were very

284 good toward novel coronavirus. That the results reported on practice toward $2019-\mathrm{nCoV}$ among

285 the respondents were similar to those reported in the Malaysian population (14) while being less

286 than the level of practices among Chinese residents (4).

287 This level of practice among the respondents attributed that the Iraqi government didn't take

288 drastic measures in reducing the spread of the disease, in addition to the low number of cases in

289 Mosul at the beginning of the pandemic (20).

290 Our results using t-tests, ANOVA and logistic regression analysis showed that there was better

291 knowledge and accurate practices associated significantly with female gender, respondents above

29250 years old, employed respondents, higher education, and married respondents.

293 Females and mothers are expected to show better knowledge and practices towards the 2019

294 novel coronavirus precautions and preventions. Similar studies in Malaysian and Saudi Arabia

295 indicated that females had more knowledge regarding novel coronavirus than males $(14,15)$.

296 The high level of knowledge and practice among the participants that are above the age of 50 in

297 our study is possibly due to understanding the higher risk of contraction and complications of the

298 disease on the elderly and people with chronic diseases (21). In our study, the respondents that

299 hold a higher degree level had a greater level of knowledge than the others. Similar findings 
medRxiv preprint doi: https://doi.org/10.1101/2020.09.11.20192542; this version posted September 11, 2020. The copyright holder for this preprint (which was not certified by peer review) is the author/funder, who has granted medRxiv a license to display the preprint in perpetuity.

It is made available under a CC-BY 4.0 International license .

300

301

302

303

304

305

306

307

308

309

310

311

312

313

314

\section{$315 \quad$ Limitations}

316 Since the study is a cross-sectional study, it was conducted within a short time during the

317 pandemic. Moreover, this study was an online survey that expected that the people with a higher 318 level of education would respond to the survey; as such, it doesn't give privilege to the

were reported within Malaysian and Pakistani university populations (14,19). A great majority of respondents confirmed that the novel coronavirus disease is more dangerous in patients with chronic diseases and the elderly. This has been confirmed from many studies published regarding the 2019 novel coronavirus disease in China $(22,23)$.

Our results reported that $17.5 \%$ of the respondents had chronic diseases such as diabetes, asthma, and severe obesity were the common diseases among our participants. A similar study among Iraqi adults indicated that the common non-communicable diseases were hypertension $(13.3 \%)$ and overweight or obese (54.6\%). Another study showed that diabetes and hypertension were the most prevalent diseases among Iraqi people $(24,25)$.

Our results were compatible with many studies that showed similar significance in terms of better knowledge and practice among the educated and employed people. $(4,14,15,26,27)$.

Finally, the results indicated that more informative novel coronavirus efforts and more intense health education should be directed toward respondents with the following socio0demographic characteristics; male respondents, respondents with lower educational levels, younger respondents, and unmarried respondents.

$$
\text { uneducated population and those with limited access to the internet. }
$$

\section{CONCLUSIONS}


medRxiv preprint doi: https://doi.org/10.1101/2020.09.11.20192542; this version posted September 11, 2020. The copyright holder for this preprint (which was not certified by peer review) is the author/funder, who has granted medRxiv a license to display the preprint in perpetuity.

It is made available under a CC-BY 4.0 International license .

321 In general, the current study provided a comprehensive screening of the knowledge and

322 practices of the population in Mosul city toward the 2019 novel coronavirus. The participants

323 had a high level of knowledge about the virus, and good practice towards using protective

324 measures, which is significant towards controlling the spread of the virus. The study

325 recommends developing informative novel coronavirus related campaigns targeted specifically

326 towards younger males, lower educated, and unemployed people were living in Mosul city.

327 Furthermore, interventions that encourage the provision and use of free personal protective

328 equipment (PPE) such as face mask should be developed as this will help curb the spreading of

329 the virus. In the same vein, the Iraqi government should take more effort to control the spread of

330 the disease.

331

332 ACKNOWLEDGMENT

333 The authors thank the University of Sharjah and respondents who agree to participate in the

334 study. Also, we gratefully acknowledge Mr. Ahmed Omar Address - College of Medicine for the

335 critical edition of English grammar.

336

337 CONFLICTS OF INTEREST

338 The authors declare no conflict of interest.

339

340 FUNDING

341 This research received no external funding

342 AUTHOR CONTRIBUTIONS 
medRxiv preprint doi: https://doi.org/10.1101/2020.09.11.20192542; this version posted September 11, 2020. The copyright holder for this preprint (which was not certified by peer review) is the author/funder, who has granted medRxiv a license to display the preprint in perpetuity.

It is made available under a CC-BY 4.0 International license .

343

344

345

346

347

348

349

350

351

352

353

354

355

356

357

358

359

360

361

362

363

364

365

366

367

368

369

370

B.Q.S. Conceptualization, design of the study, data collection, resources, and wrote the paper, R.A contributed to the statistical analysis, and O.A.B Revise and edit the text, All authors have read and agreed to the published version of the manuscript.

\section{REFERENCES}

1. Bedford J, Enria, D, Giesecke J, Heymann DL, Ihekweazu C, Kobinger G. et al. COVID19: towards controlling of a pandemic. The Lancet 2020; 395: 1015-1018. https://doi.org/10.1016/S0140-6736(20)30673-5

2. Centers for Disease Control and Prevention (CDC). Coronavirus Disease 2019 (COVID19), https://www.cdc.gov/media/dpk/diseases-and-conditions/coronavirus/coronavirus2020.html : 2020

3. World Health Organization (WHO). Coronavirus disease (COVID-19) pandemic, https://www.who.int/emergencies/diseases/novel-coronavirus2019?.gclid=Cj0KCQjwhIP6BRCMARIsALu9LfkmGQaE5XRz5j9ckkzQ2Yrb0Zj0pm27ut G7cFS--zxdlxRnSAdlFDkaAvtJEALw_wcB: 2020

4. Zhong BL, Luo W, Li HM, Zhang QQ, Liu XG, Li WT, Li Y. Knowledge, attitudes, and practices towards COVID-19 among Chinese residents during the rapid rise period of the COVID-19 outbreak : a quick online cross-sectional survey. Int J Biol Sci 2020;16 (10): 1745-1752.

5. Habibzadeh P, Stoneman EK. The Novel Coronavirus: A Bird's Eye View. The International Journal of Occupational and Environmental Medicine 2020;11(2):65-71. 
medRxiv preprint doi: https://doi.org/10.1101/2020.09.11.20192542; this version posted September 11, 2020. The copyright holder for this preprint (which was not certified by peer review) is the author/funder, who has granted medRxiv a license to display the preprint in perpetuity.

It is made available under a CC-BY 4.0 International license .

371

372

373

374

375

376

377

378

379

380

381

382

383

384

385

386

387

388

389

390

391

392

393

394

395

396

397

398

399

400

401

402

6. OCHA. United nation office for the coordination of humanitarian affairs, https://www.unocha.org/iraq: 2020

7. Al-Malkey MK, Al-Sammak MA. Incidence of the COVID-19 in Iraq - Implications for travelers. Travel Med Infect Dis 2020; 13: 101739.

8. Mosul: MSF works on dual front of COVID-19 and lifesaving, https://www.msf.org/mosuliraq-msf-dual-front-covid-19-and-lifesaving-care: 2020

9. Mikhael EM, Al-Jumaili AA. Can developing countries face novel coronavirus outbreak alone. The Iraqi situation, Public Health in Practice 2020; 1:100004.

10. World Health Organization (WHO). Novel Coronavirus (2019-nCoV) Advice for the Public, https://www.who.int/emergencies/diseases/novel-coronavirus-2019/advice-forpublic: 2020

11. World Health Organization (WHO). Novel Coronavirus (2019-nCoV) Advice for the Public, https://www.who.int/emergencies/diseases/novel-coronavirus-2019/advice-forpublic: 2020

12. CDC. Get the Facts About Coronavirus, https://www.cdc.gov/coronavirus/2019ncov/index.html: 2020

13. Conroy R. Sample size: a rough guide. Ethics (Medical Research) Committee, http://www.beaumontethics.ie/docs/application/samplesizecalculation.pdf: 2015

14. Israel GD. Determining the sample size. Gainesville: University of Florida; 1992. Report No. Fact Sheet PEOD-6.

15. Azlan AA, Hamzah MR, Sern TJ, Ayub SH, MohamadE. Public knowledge, attitudes and practices towards COVID-19: A cross-sectional study in Malaysia. PLoS ONE 2020; 15(5): $\mathrm{e} 0233668$

16. Al-Hanawi MK, Angawi K, Alshareef N, Qattan AMN, Helmy HZ, Abudawood Y, Alqurashi M, Kattan WM, Kadasah NA, Chirwa GC, Alsharqi O. Knowledge, Attitude and Practice Toward COVID-19 Among the Public in the Kingdom of Saudi Arabia: A CrossSectional Study. Frontiers in Public, health 2020; 8:217.

17. Saqlain M, Munir MM, Rehman BSU, Gulzar CA, Naz DS, Ahmed EZ, Tahir FAH, Mashhoodg AM. Knowledge, attitude, practice and perceived barriers among healthcare workers regarding COVID-19: a cross-sectional survey from Pakistan. J Hosp Infect 2020; 105(3): 419-423. 
medRxiv preprint doi: https://doi.org/10.1101/2020.09.11.20192542; this version posted September 11, 2020. The copyright holder for this preprint (which was not certified by peer review) is the author/funder, who has granted medRxiv a license to display the preprint in perpetuity.

It is made available under a CC-BY 4.0 International license .

403

404

405

406

407

408

409

410

411

412

413

414

415

416

417

418

419

420

421

422

423

424

425

426

427

428

429

430

431

432

433

434

435

436

18. Khasawneh AI, Humeidan AA, Alsulaiman JW, Bloukh S, Ramadan M, Al-Shatanawi TN, Awad HH, Hijazi WY, Al-Kammash KR, Obeidat N, Saleh T. and Kheirallah KA. Medical Students and COVID-19: Knowledge, Attitudes, and Precautionary Measures. A Descriptive Study from Jordan. Frontiers in Public Health 2020; 8:253.

19. Abdelhafz AS, Mohammed Z, Ibrahim ME, Ziady HH, Alorabi M, Ayyad M, Sultan EA. Knowledge, Perceptions, and Attitude of Egyptians Towards the Novel Coronavirus Disease (COVID $\square$ 19). Journal of Community Health 2020; 45:881-890

20. Salman M, Mustafa ZU, Asif N, Zaidi HA, Hussain K, Shehzadi N, Khan TM, Saleem Z. Knowledge, attitude, and preventive practices related to COVID $\square$ 19: a cross $\square$ sectional study in two Pakistani university populations. Drugs \& Therapy Perspectives 2020; 36:319_ 325

21. Revitalising the commercial activities in the country and to ease the burden on the workers, https://www.thenational.ae/world/mena/coronavirus-iraq-eases-restrictions-despite-lack-ofrespite-from-covid-19-1.1051563: 2020

22. Cao J, Hu X, Cheng W, Yu L, Tu W-J, Liu Q. Letter to the editor: clinical features and short-term outcomes of 18 patients with coronavirus disease 2019 in intensive care unit. Intensive Care Med 2020, https://doi.org/10.1007/s00134-020-05987-7

23. Li, LQ, Huang, T, Wang YQ, Wang ZP, Liang Y, Huang TB, Zhang HY, Sun W, Wang Y. COVID $\square 19$ patients' clinical characteristics, discharge rate, and fatality rate of meta $\square$ analysis. Journal of Medical Virology 2020; $1-7$.

24. Liang W, Guan W, Chen R, Wang W, Li J, Xu K. et al. Cancer patients in SARS-CoV-2 infection: A nationwide analysis in China. The Lancet Oncology 2020; 21(3):335-337.

25. Yun K, Hebrank K, Graber L K, Sullivan M C, Chen I, Gupta J. High Prevalence of Chronic Non-Communicable Conditions Among Adult Refugees. J Community Health 2012; 37(5):1110-1118. 
437 26. Hussain A, Lafta RK. Burden of non-communicable diseases in Iraq after the 2003 war. $438 \quad$ Saudi medical journal 2019; 40(1):72-78

439

440

441

442

443

444

445

446

447

448

449

450

451

452

453

27. Rugarabamu S, Ibrahim M, Byanaku A. Knowledge, attitudes, and practices (KAP) towards COVID-19: A quick online cross-sectional survey among Tanzanian residents. medRxiv preprint2020; doi: https://doi.org/10.1101/2020.04.26.20080820.t

28. Hager E, Odetokun IA, Bolarinwa O, Zainab A, Okechukwu O, Al-Mustapha AI. Knowledge, attitude, and perceptions towards the 2019 Coronavirus Pandemic: A binational survey in Africa. PloS one. 2020;15(7): e0236918.

TABLES AND FIGURES: 
medRxiv preprint doi: https://doi.org/10.1101/2020.09.11.20192542; this version posted September 11, 2020. The copyright holder for this preprint (which was not certified by peer review) is the author/funder, who has granted medRxiv a license to display the preprint in perpetuity.

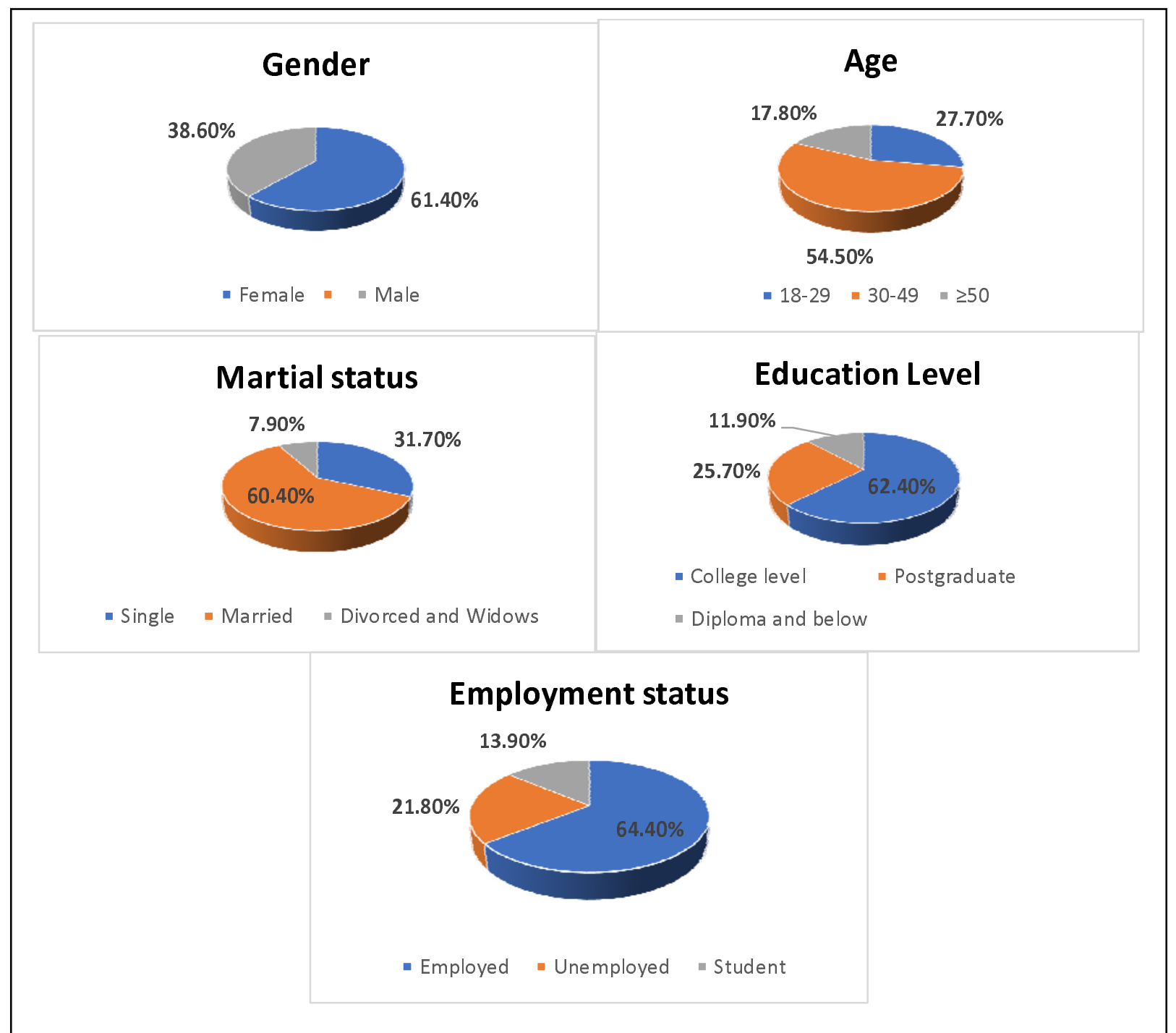

454 Fig. 1. Socio-demographic characteristics of the participants Mosul, Iraq $(n=909)$. 
medRxiv preprint doi: https://doi.org/10.1101/2020.09.11.20192542; this version posted September 11, 2020. The copyright holder for this preprint (which was not certified by peer review) is the author/funder, who has granted medRxiv a license to display the preprint in perpetuity.

It is made available under a CC-BY 4.0 International license .

464 Figure. 2.: Prevalence of chronic diseases reported by people in the Mosul, Iraq $(\mathrm{n}=909)$

465

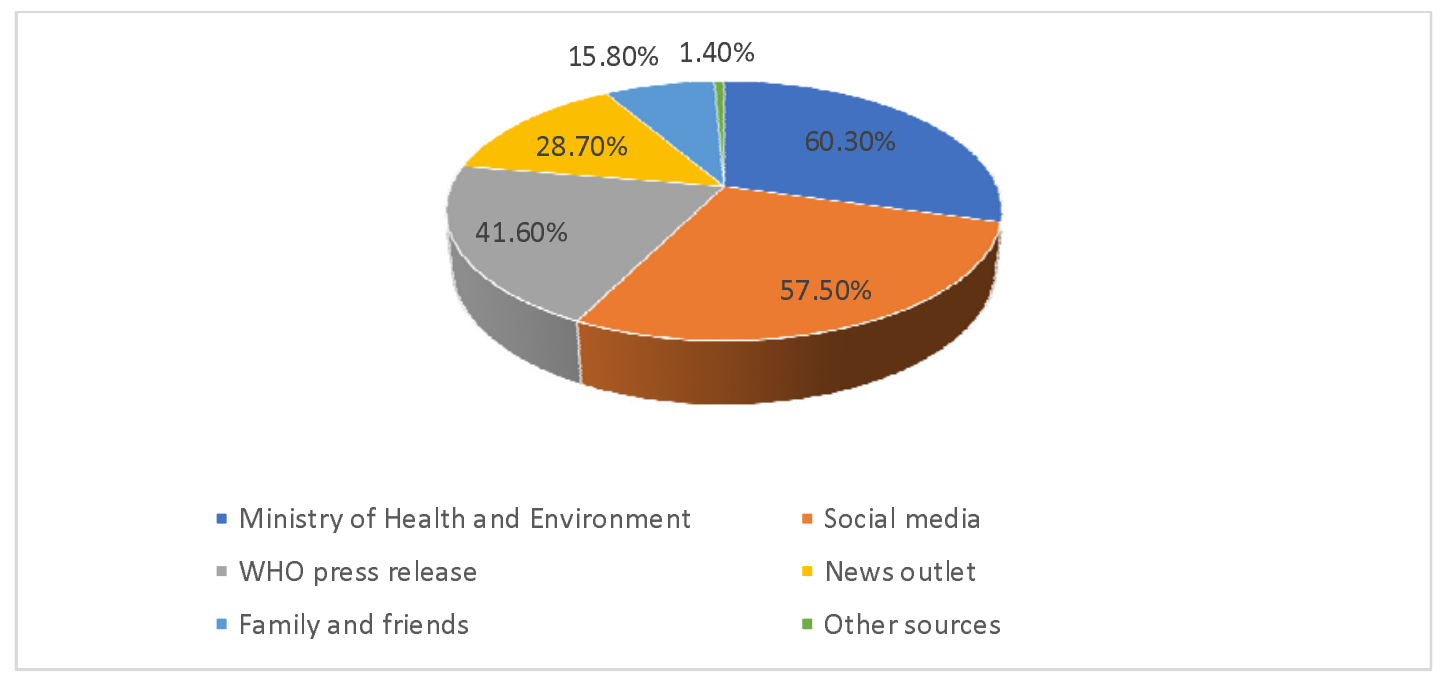

466

467

468

Table 1. General knowledge of participants about novel coronavirus in Mosul, Iraq ( $\mathrm{n}=909)$

\begin{tabular}{|c|c|c|c|}
\hline Knowledge questions & & Frequency (\%) & MEAN \pm SD \\
\hline \multirow{3}{*}{$\begin{array}{l}\mathrm{K}: 1 \text { Novel coronavirus is caused by } \\
\text { virus }\end{array}$} & Yes & $837(92.1)$ & \multirow{3}{*}{$1.13 \pm 0.460$} \\
\hline & No & $27(3.0)$ & \\
\hline & Not sure & $45(5.0)$ & \\
\hline \multirow{3}{*}{$\begin{array}{l}\mathrm{K}: 2 \text { Incubation period range of novel } \\
\text { coronavirus is } 2-14 \text { day }\end{array}$} & Yes & $855(94.1)$ & \multirow{3}{*}{$1.07 \pm 0.291$} \\
\hline & No & $45(5.0)$ & \\
\hline & Not sure & $9(1.0)$ & \\
\hline \multirow{3}{*}{$\begin{array}{l}\text { K3: The main clinical symptoms of } \\
\text { Novel coronavirus are fever, dry cough, } \\
\text { tiredness, and breathing difficulties }\end{array}$} & Yes & $873(96.0)$ & \multirow{3}{*}{$1.08 \pm 0.390$} \\
\hline & No & $0(0)$ & \\
\hline & Not sure & $36(4.0)$ & \\
\hline \multirow{3}{*}{$\begin{array}{l}\text { K4: No vaccine against novel } \\
\text { coronavirus }\end{array}$} & Yes & $657(72.3)$ & \multirow{3}{*}{$2.10 \pm 0.517$} \\
\hline & No & $81(8.9)$ & \\
\hline & Not sure & $171(18.8)$ & \\
\hline \multirow{3}{*}{$\begin{array}{l}\text { K5: No active treatment for novel } \\
\text { coronavirus }\end{array}$} & Yes & $576(63.4)$ & \multirow{3}{*}{$2.23 \pm 0.561$} \\
\hline & No & $63(6.9)$ & \\
\hline & Not sure & $270(29.7)$ & \\
\hline \multirow{3}{*}{$\begin{array}{l}\text { K6: Novel coronavirus spreads via } \\
\text { respiratory droplets of infected people }\end{array}$} & Yes & $846(93.1)$ & \multirow{3}{*}{$1.13 \pm 0.481$} \\
\hline & No & $9(1)$ & \\
\hline & Not sure & $54(5.9)$ & \\
\hline
\end{tabular}


medRxiv preprint doi: https://doi.org/10.1101/2020.09.11.20192542; this version posted September 11 , 2020. The copyright holder for this preprint (which was not certified by peer review) is the author/funder, who has granted medRxiv a license to display the preprint in perpetuity.

It is made available under a CC-BY 4.0 International license .

K7: Novel coronavirus is spread through touching contaminated surfaces

K8: Novel coronavirus can be transmitted through eyes, in addition to nose and mouth

K9: A person with novel coronavirus having no fever cannot infect others

K10: Children and young adults don't need to take measures to prevent the infection by the novel coronavirus

K11: We should stay at home and go out only when it is necessary

K12: To prevent the spread of novel coronavirus, individuals should avoid going to crowded places if it's not necessary

K13: The novel coronavirus may be more dangerous in patients with chronic diseases and elderly

K14: People who have contact with someone infected with the novel coronavirus should be immediately isolated in a proper place

K15: Smokers are likely to be more vulnerable to novel coronavirus

\begin{abstract}
Yes
No
\end{abstract}

Not sure

\section{Yes}

No

Not sure

$\begin{array}{cc}\text { Yes } & \mathbf{1 6 2}(\mathbf{1 7 . 8}) \\ \text { No } & 540(59.4) \\ \text { Not sure } & 207(22.8) \\ \text { Yes } & \mathbf{1 8}(\mathbf{2}) \\ \text { No } & 855(94.1)\end{array}$

Not sure

\section{Yes}

No

Not sure

$$
\begin{aligned}
& \text { Yes } \\
& \text { No }
\end{aligned}
$$

Not sure

Yes

No

Not sure

Yes

No

Not sure

Yes

No

Not sure
846 (93.1)

9 (1)

54 (5.9)

747 (82.2)

108 (11.9)

$1.24 \pm 0.548$

54 (5.9)

$36(4)$

693 (76.2)

$216(23.8)$

$1.48 \pm 0.852$

$0(0)$

909 (100)

$0(0)$

$1.00 \pm 0.00$

$0(0)$

873 (96)

9 (1)

909 (100)

720 (79.2)

99 (10.9)
27 (3)

$0(0)$

$1.00 \pm 0.00$

$0(0)$

$90(9.9)$

$1.07 \pm 0.352$

$86.08 \%$

470 Table 2. Practices of participants toward novel coronavirus in Mosul, Iraq ( $n=909)$ 
P1: Have you started to wash or sanitize your hands regularly?

P2: Have you washing your hands for 20 Sec or more?

P3: Do you use sanitizer if the soap is not available

P4: Do you wear a mask when you go outside?

P:5 Do you keep distance between you and others when you go outside?

P6: Do you keep 2 meters distance between you and others?

P7: Did you stop going to crowded places recently?

P8: Did you stop visiting your relatives and friends during the outbreak?

P9: Did you stop kissing your relatives and friends when you meet them?

P10: Did you stop handshaking with others?

P11: Do you wash or sterilize your hands after dealing with cash?

P12: Did you stop sharing your eating utensils and food with others?

P13: Do you follow regular updates on Novel coronavirus?

\begin{tabular}{|c|c|c|}
\hline Always & $837(92.1)$ & \\
\hline Sometime & $72(7.9)$ & $1.16 \pm 0.540$ \\
\hline Never & $0(0)$ & \\
\hline Always & 702 (77.2) & \\
\hline Sometime & $0(0.0)$ & $1.38 \pm 0.807$ \\
\hline Never & $207(22.8)$ & \\
\hline Always & $837(92.1)$ & \\
\hline Sometime & $0(0.0)$ & $1.13 \pm 0.501$ \\
\hline Never & $72(8)$ & \\
\hline Always & $756(83.2)$ & \\
\hline Sometime & 135 (14.9) & $1.32 \pm 0.717$ \\
\hline Never & $18(2.0)$ & \\
\hline Always & $657(72.3)$ & \\
\hline Sometime & $0(0)$ & $1.55 \pm 0.896$ \\
\hline Never & $252(27.7)$ & \\
\hline Always & $333(36.6)$ & \\
\hline Sometime & $45(5.0)$ & $1.82 \pm 0.814$ \\
\hline Never & $531(58.4)$ & \\
\hline Always & $801(88.1)$ & \\
\hline Sometime & $90(9.9)$ & $1.22 \pm 0.607$ \\
\hline Never & $18(2.0)$ & \\
\hline Always & $630(69.3)$ & \\
\hline Sometime & $189(20.8)$ & $1.51 \pm 0.816$ \\
\hline Never & $90(9.9)$ & \\
\hline Always & $594(65.3)$ & \\
\hline Sometime & $252(27.7)$ & $1.62 \pm 0.889$ \\
\hline Never & $63(6.9)$ & \\
\hline Always & $702(77.2)$ & \\
\hline Sometime & $198(21.8)$ & $1.45 \pm 0.827$ \\
\hline Never & $9(1.0)$ & \\
\hline Always & $738(81.2)$ & \\
\hline Sometime & 108 (11.9) & $1.31 \pm 0.671$ \\
\hline Never & $63(6.9)$ & \\
\hline Always & $684(75.2)$ & \\
\hline Sometime & $144(15.8)$ & $1.41 \pm 0.747$ \\
\hline Never & 81 (8.9) & \\
\hline Always & $693(76.2)$ & \\
\hline Sometime & $189(20.8)$ & $1.45 \pm 0.815$ \\
\hline Never & $27(3.0)$ & \\
\hline \multicolumn{3}{|c|}{$75.84 \%$} \\
\hline
\end{tabular}


474

475

476

477

478

479

480

481

482

483

484
Table 3. Association between socio-demographic characteristics with knowledge (K) and practices $(\mathrm{P})$ of participants.

\begin{tabular}{|c|c|c|c|c|c|}
\hline \multicolumn{6}{|c|}{ Knowledge of participants } \\
\hline Variables & & Frequency $(\%)$ & MEAN \pm SD & $\mathbf{t} / \mathbf{F}$ & P-value \\
\hline \multirow[t]{2}{*}{ Gender } & Female & $558(61.4 \%)$ & $13.19 \pm 1.70$ & \multirow{2}{*}{6.57} & \multirow{2}{*}{0.000} \\
\hline & Male & $351(38.6 \%)$ & $12.46 \pm 1.51$ & & \\
\hline \multirow[t]{3}{*}{ Age } & $18-29$ & $252(27.7 \%)$ & $12.35 \pm 1.63$ & \multirow{3}{*}{64.54} & \multirow{3}{*}{0.000} \\
\hline & $30-49$ & $495(54.5 \%)$ & $12.80 \pm 1.70$ & & \\
\hline & $\geq 50$ & $162(17.8 \%)$ & $14.11 \pm 0.87$ & & \\
\hline \multirow[t]{3}{*}{ Marital status } & Single & $288(31.7 \%)$ & $12.40 \pm 1.47$ & \multirow{3}{*}{20.83} & \multirow{3}{*}{0.000} \\
\hline & Married & $549(60.4 \%)$ & $13.11 \pm 1.74$ & & \\
\hline & Others & $72(7.9 \%)$ & $13.37 \pm 1.32$ & & \\
\hline \multirow[t]{3}{*}{ Education level } & College degree & $567(62.4 \%)$ & $12.84 \pm 1.62$ & \multirow{3}{*}{9.28} & \multirow{3}{*}{0.000} \\
\hline & $\begin{array}{c}\text { Postgraduate } \\
\text { degree }\end{array}$ & $234(25.7 \%)$ & $13.26 \pm 1.51$ & & \\
\hline & Others & $108(11.9 \%)$ & $12.50 \pm 2.07$ & & \\
\hline \multirow[t]{3}{*}{ Employment status } & Employed & $585(64.4 \%)$ & $13.12 \pm 1.61$ & \multirow{3}{*}{17.44} & \multirow{3}{*}{0.000} \\
\hline & Unemployed & $198(21.8 \%)$ & $12.72 \pm 1.93$ & & \\
\hline & Student & $126(13.9 \%)$ & $12.21 \pm 1.21$ & & \\
\hline \multicolumn{6}{|c|}{ Practices of participants } \\
\hline Variables & & Frequency $(\%)$ & MEAN \pm SD & $\mathbf{t} / \mathbf{F}$ & P-value \\
\hline \multirow[t]{2}{*}{ Gender } & Female & $558(61.4 \%)$ & $21.85 \pm 2.61$ & \multirow{2}{*}{3.8} & \multirow{2}{*}{0.000} \\
\hline & Male & $351(38.6 \%)$ & $21.1 \pm 3.31$ & & \\
\hline \multirow[t]{3}{*}{ Age } & $18-29$ & $252(27.7 \%)$ & $21.64 \pm 2.89$ & \multirow{3}{*}{12.14} & \multirow{3}{*}{0.000} \\
\hline & $30-49$ & $495(54.5 \%)$ & $21.21 \pm 3.04$ & & \\
\hline & $\geq 50$ & $162(17.8 \%)$ & $22.50 \pm 2.32$ & & \\
\hline \multirow[t]{3}{*}{ Marital status } & Single & $288(31.7 \%)$ & $21.87 \pm 2.87$ & \multirow{3}{*}{2.80} & \multirow{3}{*}{0.061} \\
\hline & Married & $549(60.4 \%)$ & $21.45 \pm 2.99$ & & \\
\hline & Others & $72(7.9 \%)$ & $21.12 \pm 2.48$ & & \\
\hline
\end{tabular}


medRxiv preprint doi: https://doi.org/10.1101/2020.09.11.20192542; this version posted September 11, 2020. The copyright holder for this preprint (which was not certified by peer review) is the author/funder, who has granted medRxiv a license to display the preprint in perpetuity.

It is made available under a CC-BY 4.0 International license .

$\begin{array}{llll}567(62.4 \%) & 21.4 \pm 3.07 & & \\ 234(25.7 \%) & 21.75 \pm 2.77 & 0.955 & 0.385 \\ 108(11.9 \%) & 21.73 \pm 2.36 & & \\ & & & \\ 585(64.4 \%) & 21.63 \pm 2.96 & & \\ 198(21.8 \%) & 21.18 \pm 2.92 & 2.48 & 0.084 \\ 126(13.9 \%) & 21.85 \pm 2.67 & & \end{array}$

Employment status
Employed Unemployed Student

\author{
College degree \\ degree \\ Others
}

Table 4: Binary logistic regression analysis on factors significantly associated with mean knowledge and practices about novel coronavirus of the participants, Mosul-Iraq

\begin{tabular}{|c|c|c|c|}
\hline \multicolumn{4}{|c|}{ Knowledge (> 12 and < 12) } \\
\hline Variable & $\beta$ & OR (CI 95\%) & P-value \\
\hline $\begin{array}{l}\text { Age }(\geq 50 \text { vs. } 18-29) \\
\text { Age }(\geq 50 \text { vs. } 30-49)\end{array}$ & - & - & $0.001 *$ \\
\hline $\begin{array}{l}\text { Marital status (others vs. married } \\
\text { and single) }\end{array}$ & - & - & $0.036 *$ \\
\hline $\begin{array}{l}\text { Employment status (employed vs. } \\
\text { unemployed and students) }\end{array}$ & - & - & $0.000 *$ \\
\hline $\begin{array}{l}\text { Employment status (unemployed } \\
\text { vs. employed) }\end{array}$ & -1.79 & $0.167(0.103-0.270)$ & $0.000 *$ \\
\hline \multicolumn{4}{|c|}{ Practice $(>21$ and $<21)$} \\
\hline Variable & $\boldsymbol{\beta}$ & OR (CI 95\%) & P-value \\
\hline Gender (male vs. female) & -0.458 & $0.633(0.464-0.863)$ & $0.004 *$ \\
\hline Age (18-29 vs. $\geq 50)$ & -0.790 & $0.454(0.261-0.788)$ & $0.005^{*}$ \\
\hline Age (30-49 vs. $\geq 50)$ & -0.890 & $0.411(0.266-0.635)$ & $0.000 *$ \\
\hline $\begin{array}{l}\text { Education level (others level vs. } \\
\text { postgraduate }\end{array}$ & 1.450 & $4.263(2.206-8.236)$ & $0.000 *$ \\
\hline $\begin{array}{l}\text { Employment status (unemployed } \\
\text { vs. employed) }\end{array}$ & -1.215 & $0.297(0.158-0.558)$ & $0.006^{*}$ \\
\hline
\end{tabular}

